\title{
ACTIVATING ROLE OF INTERACTIVE DIDACTIC MATERIALS IN TEACHING COMPUTER SUBJECTS
}

\author{
Renata Lis ${ }^{1}$ \\ 1 Department of Fundamentals of Technology, Lublin University of Technology, Nadbystrzycka 38, 20-618 \\ Lublin, Poland, e-mail: r.lis@pollub.pl
}

Received: 2015.10.06

Accepted: 2015.11.14

Published: 2015.12.04

\begin{abstract}
In the days of the visual culture a manner of the transmission of information plays a very important role. Adopting a technique of the join of text, graphics, sound and animation in frames of the uniform structure of presenting data, particularly in the education, it is possible to achieve good results in handing over of knowledge than at using only one of the media. The article presents the results of research devoted to the influence of visual and textual teaching materials, on the level of assimilation of knowledge subjects and their involvement in the assimilation of content. The analysis of the results showed that the visualization of teaching content is a factor significantly activating the educational process and affecting the level of knowledge assimilation.
\end{abstract}

Keywords: interactivity, learning materials, computer subjects, multimedia course.

\section{INTRODUCTION}

In education of the computer subjects it is necessary to use different kinds of teaching materials, usually in a digital form. Creating such materials requires the transfer of some components of the educational process of verbal communication on the content presented visually. Such ingredients are, for example, focus techniques and maintaining motivation to learn. Thus, the digital educational materials should be much more attractive and varied than those used in traditional teaching $[3,5]$.

Currently, mechanical acquisition of a large piece of theoretical materials lost its importance, and gaining the acquisition of knowledge through practical activities, involving in the educational process. The publication of material on the Internet does not guarantee that they will be effectively processed by the recipients. It is very important that the learning environment were designed so that in itself motivate learners to engage in selfsolve. This will result from the use of interactive visual educational materials, which will ensure an optimum level of activation of the learners.

\section{TYPES OF INTERACTIVE LEARNING MATERIALS}

The effectiveness of knowledge transfer, also depends on the means and materials. In education of information technology typical laboratory instructions are used either, either on paper or digital, where a learner displays text instructions on the screen. These instructions contain only static visuals in a form of illustrations and photos. However, more and more teachers are choosing multimedia forms of knowledge transfer, e.g. e-learning courses, containing not only text and picture but also the dynamic visualizations, i.e.: animation, video and interactivity.

In the e-learning courses, interactivity is achieved by making the student decisions and perform using digital devices certain actions, which determine the further course of the course [1]. The user can click on an element of the course, triggers a programmed algorithm. Thanks to these capabilities, the user ceases to be a passive and begins to participate and / or co-create the course. Therefore, the whole process of learning and skills acquisition occurred, the student 
must actively participate in it. This activity will take different levels, depending on the nature of the interactive learning materials.

Interactions in multimedia learning materials can be divided into three groups: "Click", "Think and click", "Do something and click" [6]. "Click" is the simplest type of interaction, which consists in undertaking appropriate steps to move to the next step of the course. The student in order to move to the next screen of the course must perform "Click View". If you choose a correct option, it goes further, otherwise the slide of the course does not change. This type of interaction does not require a major commitment from the student, he just needs to click on the corresponding interactive element on the screen. Often, this interaction requires the student to take simple decisions and choose one of two options: "YES" or "NO". "Think and click" is another level of interaction that requires greater involvement from the user. In this case, the student must make a decision based on information provided and choose one of the options proposed. The user must understand a rule and apply it in practice. In this case, just click the appropriate option is a consequence of the thought process.
Figure 2 shows an example of the interaction Drag and Drop. User based on a previously absorbed information must answer the question posed in the command and choose the correct answer. Sometimes they are also the kinds of activities in which the emphasis is not only to present the correct result, but also the way of reaching it. A good practice is to prepare for the participant's of training manual activities whose exercise step by step allows for example to carry out the experiment. Thanks to the self-observation and focusing on the correct execution of the next step instruction, the student has the opportunity to absorb and consolidate knowledge.

"Do something and click" combines a technical and choose one of the options, which is a consequence of the use of the knowledge. This type of interaction is important in situations where, besides knowledge also counts the speed of decision. Figure 3 shows an example of such an interactive exercise. During this exercise, the student has to complete two tasks. First, it must play and listen to the recording contained in the course, and then based on that record, answer the questions.

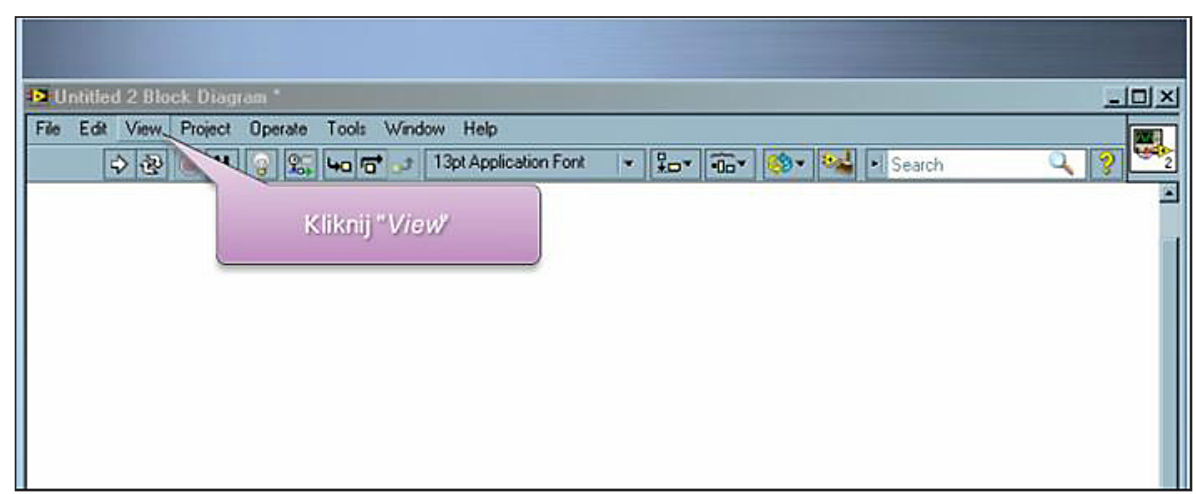

Fig. 1. Example of "Click" type of interaction [2]

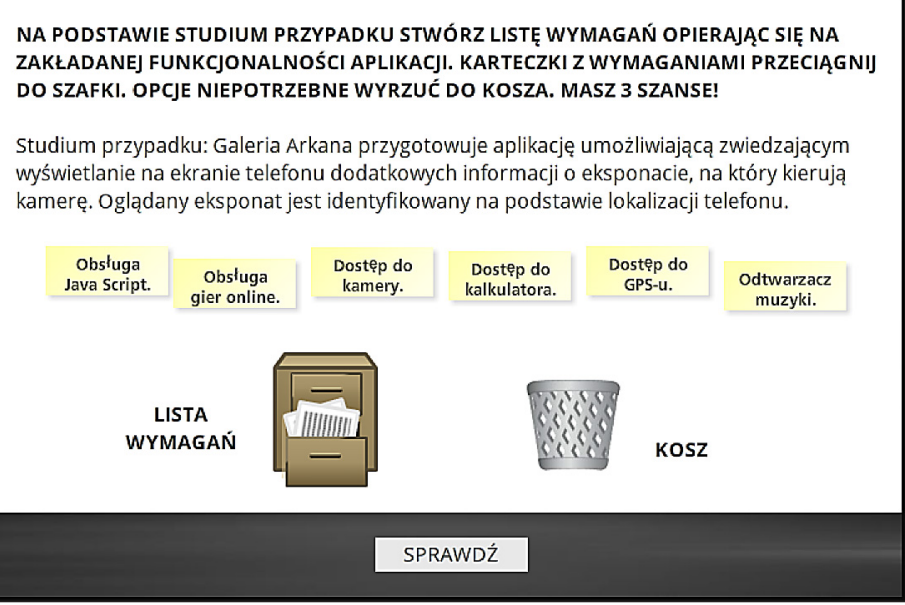

Fig. 2. Example of "Drag and Drop" type of interaction [4] 


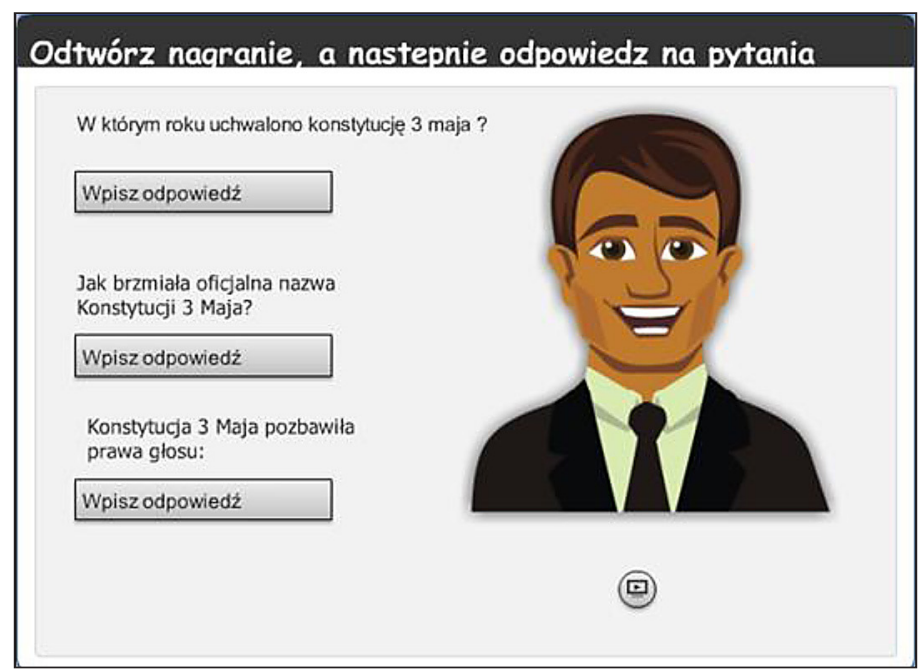

Fig. 3. Example of „Do something and click” type interactive material [4]

\section{METHODOLOGY}

\section{Design}

The aim of this study was to determine the effect of different types of teaching materials on the effectiveness of education of information technology and to determine what kind of teaching materials are activating. In order to achieve this ambitious objective in the study used three types of teaching materials in teaching operating the new computer program. The first material had a form of a printed manual containing a detailed description of the laboratory step by step how to perform the exercise without visualization. The second material is also printed manual laboratory, with an exception that contains static visualizations in a form of screenshots depicting the execution of the exercise. A third material was in a form of a multimedia course that contains such dynamic visualizations, like the interactive exercises and simulations of the program. The content of all the material was the same.

\section{Procedure and participants}

The study was conducted in two stages. The first consist of assigned to subjects with teaching materials and the other in carrying out exercises to check the acquired knowledge and skills.

The study was conducted in the classroom with the subject Multimedia systems, majoring in information technology and technical education, second degree full-time studies of Technical University of Lublin in the summer semester 2014/2015. The study involved 59 students. In a view of the purpose of the study, the students were divided into three groups. The first group worked with printed manual laboratory containing only text. The second group with a printed manual laboratory containing static graphics and multimedia and the third of course with interaction. All the groups worked with computers in the same computer lab but at a different time.

After reviewing the contents of teaching materials, surveyed have been tested in the area of acquired knowledge and computer skills. Their task was to do alone an exercise with computers in the newly-known program. Therefore, measuring the effectiveness of education consisted of checking by the teacher on which level tested has done checking exercise.

In addition, after completing the exercise, the study took part in the survey assessing particular types of teaching materials. The participants were allocated the time of 90 minutes.

\section{RESULTS AND DISCUSSION}

In the study 59 students were involved. It consisted of 18 women and 41 men. In the first group, working with printed manual laboratory containing only text, there were 20 people, including 6 women. In the second group, which received a printed manual laboratory containing static graphics there were also 20 people, including 7 women. The last group working with the multimedia course consisted of 19 people, including 5 women.

To determine the level of intellectual of respondents, they were asked for their grade point average of first degree studies. 
In the first group, $30 \%$ of respondents declared grade point average in the range of 4.1-4.5. The rest of the tested after $35 \%$ was located in the ranges 3.0-3.5, and 3,6-40. In the second group the distribution was very similar. The majority of respondents (36\%) had a grade point average with 3.0-3.5 range. In the interval $3.6-4.0,31 \%$ of respondents were placed, while $32 \%$ said they averaged between $4.1-4.5$. The third group had an average minimum of the range 3.6-4.0. Approximately $33 \%$ of respondents have indicated range of $4.1-4.5$, and $37 \%$ of the lowest interval with 3.0-3.5 range. Therefore, we can assume that the intellectual level between groups is very similar.

Operating time with didactic material was different in groups. As shown in Table 1, the longest surveyed worked with printed manual that does not contain images. The average time was 54 minutes. The observations made during the study can state that this instruction caused them many problems. Respondents could not find functions that were mentioned in the manual. Searching took them a lot of time and caused discouragement.

The group with printed paper instructions containing images, worked 42 minutes. During operation, the majority of respondents was focused on carrying out the commands in the manual.

Members of the third group assigned with didactic material work briefly, because the task took them 38 minutes. In this group, it took a lot of time not just perform actions with the instruction but also familiarization with support for multimedia course. Some subjects repeatedly viewed screens training course.

By analyzing time of the exercise checking knowledge and skills by the respondents, can state that the order is similar to that of the work- ing time with teaching materials. Test the slowest carry out exercise Group I (32 minutes), next Group II (18 minutes) and at the end the group III (14 minutes).

On this basis, it can be concluded that the majority of study memorized working with multimedia course. Average ratings of respondents obtained from checking exercise confirms this conclusion.

As is clear from the data presented in Table 2 the highest average gained 4.89 surveyed working with multimedia course. As many as 17 people from this group received very good grades and only two - the assessment of good. In the second group, the average score was a little lower, at 4.55, of which 11 people got very good grades and 9 good. In contrast, the lowest average of 4.05, was achieved in surveys from the first group. Among the respondents in this group, two people did not do the checking exercise, which resulted negative. Seven people have received very good grades, 9 - good 2 - sufficient.

From the observations made during the study, it shows that students most actively used the multimedia course. The same service of the course was engaging for respondents. They discussed various screens training and it happened that viewed some screens several times. Oral opinions of respondents indicate that they like the multimedia way to learn new software. They also state that it is a large advantage to be able to work at home using a multimedia course.

\section{CONCLUSIONS}

The analysis of results, based on studies, leads to the conclusion that the visuals and interactivity of teaching materials plays an important role in the teaching of informatics. Many activities, es-

Table 1. Average working time of teaching materials and exercise checking

\begin{tabular}{|l|c|c|c|}
\hline \multicolumn{1}{|c|}{ Description } & $\begin{array}{c}\text { Printed manual without } \\
\text { visualizations / Gr I }\end{array}$ & $\begin{array}{c}\text { Printed manual with visu- } \\
\text { alizations / GR II }\end{array}$ & $\begin{array}{c}\text { Multimedia course / } \\
\text { GR III }\end{array}$ \\
\hline Average working time of teaching materials & $54 \mathrm{~min}$ & $42 \mathrm{~min}$ & $38 \mathrm{~min}$ \\
\hline Average working time of exercise checking & $32 \mathrm{~min}$ & $19 \mathrm{~min}$ & $14 \mathrm{~min}$ \\
\hline
\end{tabular}

Table 2. Mean ratings of checking exercise with the division on the type of learning material

\begin{tabular}{|c|c|c|c|}
\hline Description & $\begin{array}{c}\text { Printed manual without } \\
\text { visualizations / Gr I }\end{array}$ & $\begin{array}{c}\text { Printed manual with visual- } \\
\text { izations/ GR II }\end{array}$ & $\begin{array}{c}\text { Multimedia course/ } \\
\text { GR III }\end{array}$ \\
\hline Mean ratings of checking exercise & 4.05 & 4.55 & 4.89 \\
\hline
\end{tabular}


pecially related to learning new software, it is not legible without visualization.

As revealed by study, the use of visualization significantly reduces the time of the transfer of knowledge and skills. However, using the teaching material interacting forces the active attitude of the learner, and supports mental commitment which will certainly lead to raising the quality of education.

In summary, it can be said that the type of teaching material used has a big impact on the level of knowledge acquisition, and thus learning outcomes. The material is more attractive to learners, that contains interactive exercises and simulations of the program, the more increases the effectiveness of education. The use of visual teaching materials in information technology education significantly increases the level of education, and leads to more active learners.

\section{REFERENCES}

1. Clark R.C., Mayer R.E.: E-learning and the science of instruction: Proven guidelines for consumers and designers of multimedia learning. Pfeiffer, 2011.

2. Dzięglewska M.: Projekt multimedialnego kursu do nauki programowania w LabView. Niepublikowana praca inżynierska, 2013.

3. Horton W.: E-learning by Design. Pfeiffer, 2006.

4. Lewicki I.: Analiza porównawcza metod wizualizacji informacji w szkoleniach e-learningowych. Niepublikowana praca magisterska, 2015.

5. Michałowicz B., Sidor D.: Metody aktywizujące w konstruktywistycznym środowisku uczenia się na e-zajęciach. In: E-learning w szkolnictwie wyższym - potencjał i wykorzystanie. FPiAKE, Warszawa 2010.

6. Woźniak J.: E-learning w biznesie. Wydawnictwa Akademickie i Profesjonalne, Warszawa 2009. 